\title{
Modelling for Industrial Land Acquisition for SEZ
}

by Dan Pranab, Guhathakurta Kousik and Gupta Shatadru

\section{Introduction}

Emergence of a new operational paradigm in manufacturing is Special Economic Zone (SEZ). SEZs are specific geographical regions that have economic laws different from and more liberal than a country's typical economic laws. Generally, it is argued that the SEZ concept is attractive because it is much easier to resolve the problems of infrastructure and governance on a limited geographical area than it is to resolve them countrywide. The goal is usually an increase in foreign direct investment (FDI) in the host country. Considering the amount of FDI inflow from developed nations of Europe and the USA to developing nations like India and China there is a clear understanding that a well-implemented and designed SEZ can bring about many desired benefits for a host-country. Increases in employment, FDI attraction, general economic growth, foreign exchange earnings, international exposure, and the transfer of new technologies and skills are just to name a few. Hence, many developing countries are also promoting the SEZs with the expectation that they will provide the engines of growth for their economies to achieve industrialization [World Bank, 1994].

A variety of terms such as industrial free zones and free trade zones are used interchangeably through most of the SEZ literature. These enclaves are referred to as special economic zones in China, maquiladoras in Mexico, Costa Rica and El Salvador, industrial free zones in Ghana, Camroon and Jordan, special export processing zones in Philippines, "Urban Enterprise Zones in USA and free economic zones in Russia (Armas and Sadni-Jallab 2002). In India, they are called special economic zones (SEZs). One of the earliest and the most famous Special Economic Zones were founded by the government of the People's Republic of China under Deng Xiaoping in the early 1980s. The most successful SEZ in China, Shenzhen, has developed from a small village into a city with a population over 10 million within 20 years. Following the Chinese examples, SEZs have been established in several countries, including Brazil, Pakistan, India, Iran are worth mentioning. Under the president ship of Alan Garcia, Peru has been slated to become a "Zona Ecomomica". In the face of fierce regional competition, South Korea too has started working strategically towards attracting investment, including the establishment of its first SEZ, called The Incheon Special Economic Zone .

\section{India and SEZ}

The SEZ scheme introduced by the government of India in April 2000 has its genesis 
in the Export Processing Zone (EPZ) scheme, which was introduced in 1965 when the first zone was set up in Kandla, Gujrat. By the late 1990s, seven more zones had come into existence. Under the new scheme, however, all the existing EPZs were converted into SEZs. However, the impact of SEZs remained far removed from expectations. Bureaucratic red tape, administrative procedures, rigid labour laws and poor infrastructure were believed to have affected the investment climate adversely in the manufacturing sector [Acharya 2006]. In order to provide a significant thrust to the policy, the government enacted the SEZ Act 2005. The act became operative in February 2006 after the SEZ rules were framed and notified.

The Act is provides for a comprehensive SEZ policy framework to satisfy the requirements of all principal stakeholders in an SEZ the developer and operator, occupant enterprise, out zone supplier and residents. Another major feature of the Act is that it claims to provide expeditious and single window clearance mechanisms which aims at overcoming the problem of getting approval from different government offices.

The Act also offers a highly attractive fiscal incentive package, which ensures

(i) exemption from custom duties, central excise duties, service tax, central sales taxes and securities transaction tax to both the developers and the units;

(ii) tax holidays for 15 years (currently the units enjoy a seven year tax holiday), i e, 100 per cent tax exemption for 5 years, 50 per cent for the next five years, and 50 per cent of the ploughed back export profits for the next five years; and

(iii) 100 per cent income tax exemption for 10 years in a block period of 15 years for SEZ developers.

The responsibility for promoting and ensuring orderly development of SEZs is assigned to the board of approval. It is to be constituted by the central government. While the central government may suo moto set up a zone, proposals of the state governments and private developers are to be screened and approved by the board. After the SEZ Rules of 2006, the board of approval has granted formal approval to 439 SEZ proposals. There are 138 valid in-principle approvals. Out of the 439 formal approvals, $195 \mathrm{SEZs}$ have been notified. The total area under these SEZs is 220,000 hectares (550,000 acres) [sezindia, 2008].

But this process of planning and development is under question, as the states in which the SEZs have been approved are facing intense protests, from the farming community, accusing the government of forcibly snatching fertile land under the ambit of the Land Acquisition Act 1894, at heavily discounted prices as against the prevailing prices in the commercial real estate industry. [Fernandes et al, 2006]. Most states including West Bengal in India that are offering land for the SEZs do not have a comprehensive rehabilitation policy. Government officials treat compensation as rehabilitation; and Compensation is defined as the average of the registered price in 
an area for three years. Thus, by using this norm the land losers are deprived of the price. Farmers had to give away their land for the bypass expressway and the Rajarhat township in Kolkata, West Bengal and were paid an average of INR 300,000(1 EURO = 64 INR, Indian National Rupee; 1 USD = 44 INR $)$ per acre when the market price in that area was INR 2 million. The situation is worse in the backward areas where price is low. In the 1980s, some farmers in Jalpaiguri district of West Bengal were paid an average of INR 1,700 per acre [Fernandes et al 2006]. However, the Government of West Bengal has promised rehabilitation in Singur because its farmers agitated against displacement. Most of those to be displaced from the 2,32,167 acres it has committed to industries [Ray 2006] will be deprived of their livelihood without alternatives.

The purpose of compensation is to compel the owner to sell the right (in monetary terms) as though the land owner is in the same position as if his land had not been taken [Rowan-Robinson and Brand, 1995]. In other words, the landowner gains the right to receive a monetary payment not less than the loss imposed on him in the public interest, but, on the other hand, no greater. The underlying theme in the compensation provisions of the land acquisition statutes is to ensure that a dispossessed landowner is no worse off and no better off as a result of his eviction (Brown, 1991). Hence, in some cases, where farmers are being offered a price that is attractive considering their meager earnings from their small holdings but does not reflect the present or potential value of the land [Ramesh et al, 1997, Murickan, 2003] the compensation cannot be considered proper.

Besides, owners of land in the surrounding areas benefit from a sharp escalation in land prices down the road. For example, in Sriperambathoor near Chennai where 750 acres of land were acquired from 1500 farmers at INR 500,000 per acre the price has now shot up to INR 8 million per acre and 15,000 farmers in the vicinity stand to benefit.

Therefore the compensation must have two elements: a down payment in cash and an upside in the form of a call option on the value of the land a few years down the road. Thus ensuring that the displaced, i.e. the farmer selling his land for a project, becomes a partner in the prosperity that the project generates. Rehabilitation needs to be pareto-optimal. Those currently displaced should be compensated to cover the value of land, and their current incomes rising at the planned growth rates of the economy need to be protected, through compensation.

The model discussed in the paper, suggests a novel land acquisition plan which envisages acquiring land in surplus to reallocate the land among those displaced from the core area. This would ensure that the appreciation of land prices or upward revision of land prices due to land development and change in land type would accrue to the ones displaced and hence it would minimize the possibilities of protests. Further, the relocation in the same habitat would the sociological change that a person undergoes as a result of rehabilitation is minimal. 


\section{Model Development}

The displaced should be compensated to cover the value of land and their current incomes. Their current incomes rising at the planned or expected growth rates of the economy need to be protected [Ray, 2006]. So the onus would be on the project to ensure that incomes of all affected are protected at their expected dynamic levels. In addition proper compensation has to be given to the sharecroppers and those depended on the common property resources (CPRs) [Pattanaik et al, 1987; NCHSE, 1986]. If the sharecroppers are registered, they are to get 25 per cent of the compensation paid to the zamindar(Land Owner) when their land is acquired. Around 250 of the sharecroppers cultivating some of the 997 acres being acquired at Singur have not been registered so they will not be compensated or resettled. Also, the 1,00o landless agricultural labourers and others like barbers who sustain themselves by rendering services to the village as a community will lose their livelihood when that land is acquired.

\section{Land Price Appreciation}

Land has always been a scarce resource and property prices follow basic economics of demand-supply. Looking at the price trend in the last few years in the areas with close proximity to Special Economic Zone the expected infrastructural development causes a sharp appreciation in land prices. As for example in Singur, 40-km. from Kolkata, before work began on the Tata Motors small-car project, the price per acre in this fertile potato-growing belt was for INR 4,50,000 which has jumped to INR 2.25 million per acre now. Similarly in Delhis neighborhood, land prices have moved from INR 2.2 million per acre to INR 10 million in Greater Noida.

The model using the above land appreciation envisages a unique land acquisition policy which is discussed below:

\section{Let}

${ }^{k}$ be extension factor indicative of the additional land to be procured $p_{1}$ be the distribution factor for reallocating to the sharecropper $p_{2}$ be the distribution factor for reallocating to the CPR dependants $r$ be the ultimate land reallocation ratio that represents the inverse of the times of price escalation $x$ be the exact area of land required to setup the industry as per layout

Then,

$$
\begin{aligned}
& \frac{k \cdot x-\left(p_{1}+p_{2}\right) \cdot x}{(1+k) x}=r \\
& k=\frac{r+\left(p_{1}+p_{2}\right)}{1-r}
\end{aligned}
$$

So if we assume the land price appreciation to be 4 times and $10 \%$ of the land to be 
acquired has to be allocated to sharecroppers

$k=\frac{0.250+0.100}{1-0.250}$

$k=0.466$

Therefore, $46.6 \%$ land has to be acquired in excess to relocate those displaced from the layout. The loss in area of land holding is compensated by proper monetary compensation at the present value of land or at the negotiated rate. The area allocated for the benefit of sharecroppers and this model inherently also addresses the problems faced by people dependent on the CPR and sharecroppers.

The compensation package can be further modified according to the expectations of land price appreciation. We discuss two models in addition to the above, with the same underlying objective but with difference in the compensation amount.

So, for a higher expected land price appreciation of 5.5 times the extension factor can be calculated as:

$$
\begin{aligned}
& k=\frac{0.181+0.100}{1-0.181} \\
& k=0.343
\end{aligned}
$$

Therefore, $34.3 \%$ of excess land has to be acquired to rehabilitate those displaced from the planned industry layout.

In a scenario of even higher expectation of land price escalation where an appreciation of 7.5 times, $\mathrm{k}$ can be calculated as :

$$
\begin{aligned}
& k=\frac{0.133+0.100}{1-0.133} \\
& k=0.268
\end{aligned}
$$

The total compensation amount borne by SEZ promoter for $x$ acres can be calculated as,

$$
=\frac{c}{u} X(1+k) x
$$

where, $c$ is the current land price

$u$ is the negotiation factor subject to $u \leq(1+k)$

The table below shows the comparative figures of different alternatives of compensation for an expected land price appreciation of 4 times.( 1 million=10 lakhs) 


\section{Nordicum-Mediterraneum}

Icelandic E-Journal of Nordic and Mediterranean Studies

\begin{tabular}{|l|l|l|l|l|l|}
\hline $\begin{array}{l}\text { Alter- } \\
\text { native }\end{array}$ & $\begin{array}{l}\text { Negotiation } \\
\text { factor, } u\end{array}$ & $\begin{array}{c}\text { Total } \\
\text { compensation } \\
\text { amount } \\
\text { borne by SEZ } \\
\text { promoter per } \\
\text { 100 acres } \\
\text { (in Rs lakhs) }\end{array}$ & $\begin{array}{c}\text { Land price } \\
\text { per 100 } \\
\text { acre } \\
\text { received } \\
\text { by } \\
\text { Landowner } \\
\text { in Rs } \\
\text { lakhs) }\end{array}$ & $\begin{array}{l}\text { Compensation } \\
\text { Land for Land } \\
\text { owners } \\
\text { (in acres) }\end{array}$ & $\begin{array}{l}\text { Compensation } \\
\text { Land for Share } \\
\text { Croppers and } \\
\text { CPR } \\
\text { dependents } \\
\text { (in acres) }\end{array}$ \\
\hline 1. & $\begin{array}{l}\text { Not } \\
\text { Applicable }\end{array}$ & 100 & 100 & 0 & 0 \\
\hline 2. & 1.466 & 100 & 58.7 & 31.3 & 10 \\
\hline 3. & 1.3 & 108.7 & 67.4 & 31.3 & 10 \\
\hline 4. & 1.2 & 117.75 & 76.45 & 31.3 & 10 \\
\hline 5. & 1.1 & 128.45 & 87.15 & 31.3 & 10 \\
\hline 6. & 1 & 141.3 & 100 & 31.3 & 10 \\
\hline
\end{tabular}

Table 1. Comparison of compensation schemes

The above information can be used to construct a graph, where each point on the line represents a unique compensation point (Figure 1).

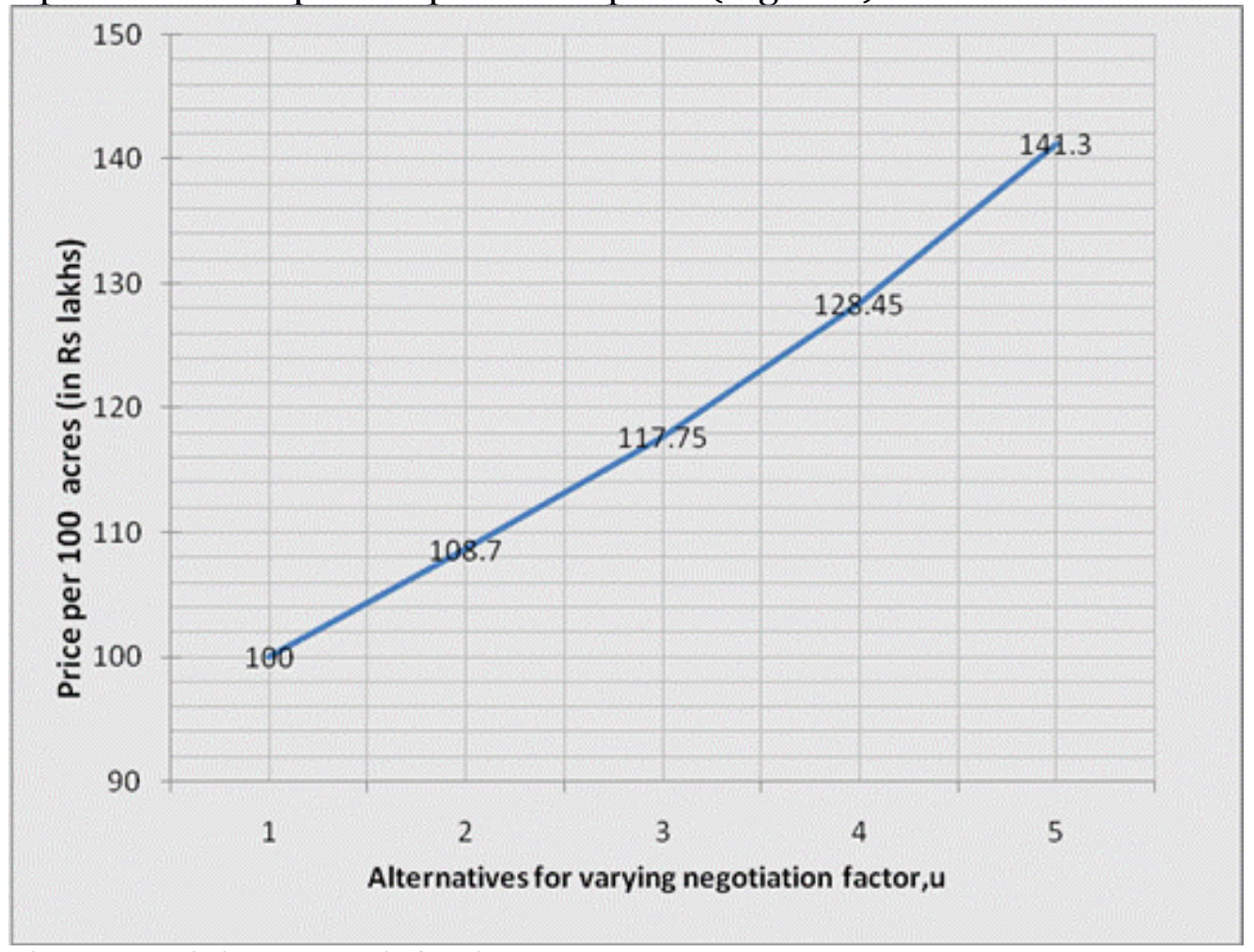

Figure 1. Claimant satisfaction curve 
Similarly the compensation curves for different expected price appreciation rates can be constructed. Further, the allocation for share croppers and CPR dependants can be varied as per requirement. These curves are indicative of the various compensation possibilities and will form the basis of negotiation. The rehabilitation package thus designed provides adequate compensation to Sharecroppers and CPR dependents and the relocation in the vicinity ensure that the benefits of land price appreciation accrues to the land owners and they are made partners in the prosperity that such projects generate.

\section{Shortcomings of the model}

The shortcomings of the developed model are the following.

1. The model is not inclusive of other kinds of compensation such as employment options, stock options that companies offer in lieu of land acquisition.

2. The acquisition of excess land that the model envisages limits its applicability to areas where land is scarce.

3. Speculative appreciation of land prices will affect the model adversely and my render may the model ineffective.

\section{Conclusion}

The number of Special Economic Zones (SEZs) globally continues to expand. SEZs account for an increasing share of international trade flows and employ a growing number of workers world-wide. In the global economy, SEZs are viewed as an important policy instrument to promote industrialization, generate employment, and for regional development through FDI from developed nations like Europe and USA. The world over and in India specifically the state is acquiring land in order to encourage private investment but fails to face the issues of rehabilitation. Economic growth is required but not by impoverishing people. That is what is happening because most Displaced Persons/Project Affected Persons who lack the skills required for industrial jobs and other benefits. But in order to encourage industrialization the state uses force to evict families that have lived on that land for generations. Through the above approach we intend to arrive at a development paradigm where the benefits reach those who pay the price.

Rehabilitation issues have been compounded by the inherent unfairness of the acquisition process [Modi, 2006]. Correction of the same would go a long way towards better and risk reducing rehabilitation. The objective of this paper is to design a model for land acquisition and relocation so as to offer a package whose basic thrust will be helping land owners get sustained income life long. So that it provides a level of compensation that would allow the affected person to retain his current living standard in the foreseeable future.

The required specification, shortcomings of the model and environment of 
development has been keenly observed. These observations clearly indicate that there is wide scope for further improvement of the model and it may pave the way for further studies and experiments to develop better models which will aim at providing equitable compensation and catapult India and other developing nations into achieving still higher rates of growth.

\section{References}

1. Acharya, S (2006): Essays on Macroeconomic Policy and Growth in India, Oxford University Press, India.

2. Armas, E.B., and M. Sadni Jallab (2002). A Review of the Role and Impact of Export Processing Zones in World Trade: The Case of Mexico, Working Paper 0207, Centre National de la Recherche Scientifique.

3. Fernandes, Walter (2004): Rehabilitation Policy for the Displaced, Economic and Political Weekly, 39, No 12, March 20-26, pp 1191-93.

4. Fernandes, Walter and Gita Bharali (2006): Development-Induced Displacement in Assam 19472000: A Quantitative and Qualitative Study of Its Extent and Nature, North Eastern Social Research, Centre, Guwahati.

5. http://sezindia.nic.in/HTMLS/about.htm..Special Economic Zones in India, Ministry of Commerce and Industry, Government of India, feb 2008

6. Jhunjhunwala, Bharat Of Land Reclamation Exchange, The Sentinel, December 7, 2006.

7. Modi, Hari. Managing Resettlement in India: Approaches, Issues and Experiences, Journal of

Refugee Studies.2006; 19: 264-267

8. Murickan, Jose, M K George, K A Emmanuel, Jose Boban and Prakash Pillai R (2003):

Development-Induced Displacement: Case of Kerala, Rawat Publications, New Delhi.

9. NCHSE (1986): Rehabilitation of Displaced Persons Due to Construction of Major Dams, Vol I, National Centre for Human Settlements and Environment, New Delhi.

10. Pattanaik, S K, B Das and A B Mishra (1987): Hirakud Dam: Expectations and Realities in

PRIA(ed), People and Dams, Society for Participatory Research in Asia, New Delhi, pp 47-59.

11. Ramesh, M K and Francis Guntipilly (1997): A Critique of the Karnataka Project-Displaced Persons Resettlement Act, 1987 in Walter Fernandes and Vijay Paranjpye (eds), op cit, pp 201-14.

12. Ray, Bibekananda (2006): Thus Capital I and II, The Statesman, December 17 and 18.

13. Sequeita, D., 1994 gender and resettlement : An overview of Impact and Planning Issues in Bank assisted Projects, Bank Resettlement review, World Bank

14. Singh, Chatrapati (1989): Rehabilitation and the Right to Property in Walter Fernandes and Enakshi Ganguly Thukral (eds), Development, Displacement and Rehabilitation: Issues for a National Debate, Indian Social Institute, New Delhi, pp 91-103.

15. Stanley, William (1996): Machkund, Upper Kolab and NALCO Projects in Koraput District, Orissa, Economic and Political Weekly, 31, No 24, June 15, pp 1533-38.

16. Vaswani, Kalpana (1992): Rehabilitation Laws and Policies: A Critical Look in Enakshi Ganguly Thukral (ed), Big Dams, Displaced People: Rivers of Sorrow, Rivers of Change, Sage Publication, New Delhi, pp 155-69.

17. World Bank (1994): Resettlement and Development: The Bankwide Review of Projects Involving Involuntary Resettlement, 1986-93, Environment Department, World Bank, Washington DC. 